\title{
Understanding the Barriers to Hospice Care in Saudi Arabia
}

\author{
Maximiliano Mendieta, PhD, Robert Buckingham, DrPH, Jordan Kietzman, BS, \\ Abdullah Helal, and Shan Parker, PhD
}

\section{Dear Editor:}

To access the students' knowledge of hospice philosophy, practice and principles, a survey of Saudi Arabian students studying at a Midwestern public university was taken.

Hospice care was established in Saudi Arabia in 1992 at the King Faisal Specialist Hospital. The key barriers to the full implementation of the analgesic ladder ${ }^{1}$ are religious, acceptance, knowledge, and availability of the medications necessary for palliative care. Access to palliative care services is limited by a lack of awareness about palliative care, knowledgeable providers, and availability of community resources. The Western concept of good death does not have the same meaning in Muslim communities, as death is anchored in the Qur'an, Allah, and faith. For palliative and hospice care, the role of religion in Saudi Arabia presents unique limitations in the use of opioids.

We surveyed all 477 Saudi Arabian students studying at a Midwestern public university and recorded a response rate of $86(19.0 \%)$ students. Questions addressed in the survey included demographics, enrollment status, and if they knew what hospice care is.

The survey showed that $74(86.0 \%)$ of 86 Saudi Arabian students attending a Midwestern public university did not know what hospice care is, and only $12(14.0 \%)$ of 86 Saudi Arabian students had some knowledge about hospice care. Interestingly, the gender distribution for Saudi Arabian students attending a Midwestern public university accounted for males at $59.0 \%$ and females at $41.0 \%$, both very close to Saudi Arabia's national demographics of $58.0 \%$ males and $42.0 \%$ females. $^{2}$ We interpreted the gender distribution at the Midwestern university to be representative of Saudi Arabia.
Caring for dying family members in Muslim society is seen as the duty of relatives, which makes having patients enter hospice care a "shirking" 3 of that responsibility. The barriers currently faced by hospice care in Saudi Arabia in part differ from the Western experience, but not from what is considered a universal philosophy of hospice care. In sum, the education of the general population and physicians about the philosophy and practice of hospice and palliative care may indeed be worthwhile for consideration to aid the terminally ill in Saudi Arabia.

\section{References}

1. Isbister $\mathrm{WH}$, Bonifant $\mathrm{J}$ : Implementation of the World Health Organization 'analgesic ladder' in Saudi Arabia. Palliat Med 2001;15:135-140.

2. Population Division of the Department of Economic and Social Affairs of the United Nations Secretariat: World Population Prospects, the 2012 Revision. esa.un.org/Wpp/ unpp/p2k0data.asp. (Last access April 16, 2015.)

3. Aljawi DM, Harford JB: Palliative care in the Muslimmajority countries: The need for more and better care. In: Chang E, Johnson A (eds): Contemporary and Innovative Practice in Palliative Care. Rijeka, Croatia: InTech Europe, 2012.

Address correspondence to: Maximiliano Mendieta, PhD Department of Public Health \& Health Sciences University of Michigan at Flint 3124 William S. White Building 303 E. Kearsley Street Flint, MI 48502

E-mail: maxmend@umflint.edu

Department of Public Health \& Health Sciences, University of Michigan at Flint, Flint, Michigan. 